Saudi Journal of Business and Management Studies Abbreviated Key Title: Saudi J Bus Manag Stud ISSN 2415-6663 (Print) IISSN 2415-6671 (Online) Scholars Middle East Publishers, Dubai, United Arab Emirates Journal homepage: https://saudijournals.com

Original Research Article

\title{
Leading Sector Using Overlay Analysis in Tasikmalaya City
}

\author{
Apip Supriadi
}

${ }^{1}$ Department of Development Economics, Faculty of Economics, Siliwangi University, Jl. Siliwangi No. 24, Kahuripan, Tawang, Tasikmalaya, West Java 46115, Indonesia

DOI: $10.36348 /$ sjbms.2022.v07i01.004 | Received: 09.12.2021 | Accepted: 20.01.2022 | Published: 29.01 .2022

*Corresponding author: Apip Supriadi

Department of Development Economics, Faculty of Economics, Siliwangi University, Jl. Siliwangi No. 24, Kahuripan, Tawang,

Tasikmalaya, West Java 46115, Indonesia

\section{Abstract}

This research aims to find out what economic sectors have the potential to be prioritized for development in Tasikmalaya City. This research uses descriptive and quantitative analysis. While the quantitative analysis used the Location Quotient (LQ) Model, Growth Ratio Model (MRP), and Overlay Analysis. should be a development priority by the local government of Tasikmalaya City, which is expected to increase the rate of regional economic growth in Tasikmalaya City.

Keywords: Location quotient model, growth ratio model, overlay analysis.

Copyright $\odot \mathbf{2 0 2 2}$ The Author(s): This is an open-access article distributed under the terms of the Creative Commons Attribution 4.0 International License (CC BY-NC 4.0) which permits unrestricted use, distribution, and reproduction in any medium for non-commercial use provided the original author and source are credited.

\section{BACKGROUND}

Regional economic development is a process in which local governments and their communities manage existing resources and form a partnership pattern between local governments and the private sector to create new jobs and stimulate the development of economic activity (economic growth) in the region (Arsyad, 2005).

Economic development in the regions is generally focused on economic growth efforts. It is hoped that there will be significant changes to community welfare fairly and equitably. To realize the welfare of the people, it can be measured from several indicators, including the level of education, health, social, culture, politics and security. These various measures are based on the economic level.

The economic development of Tasikmalaya City from 2018 - 2020, in total shows an increase every year, as shown in table 1 below:

Table 1: GRDP Development of Tasikmalaya City On the basis of constant prices in 2018 - 2020

\begin{tabular}{|l|l|l|l|}
\hline Business Field & $\mathbf{2 0 1 8}$ & $\mathbf{2 0 1 9}$ & $\mathbf{2 0 2 0}$ \\
\hline Agriculture, Forestry and Fisheries & 644,65 & 644,46 & 658,92 \\
\hline Mining and excavation & 1,28 & 1,29 & 1,30 \\
\hline Processing industry & $2.038,73$ & $2.196,03$ & $2.153,49$ \\
\hline Electricity and Gas Supply & 1,57 & 1,66 & 1,62 \\
\hline Water Supply, Waste Management, Waste and Recycling & 52,12 & 54,66 & 59,59 \\
\hline Construction & $2.296,04$ & $2.436,90$ & $2.333,34$ \\
\hline Wholesale and Retail Trade; Car and Motorcycle Repair & $3.567,88$ & $3.812,41$ & $3.575,05$ \\
\hline Transportation and Warehousing & $1.459,44$ & $1.543,23$ & $1.435,06$ \\
\hline Provision of Accommodation and Drinks & 724,78 & 781,52 & 753,48 \\
\hline Information and Communication & 596,84 & 651,21 & 869,82 \\
\hline Financial Services and Insurance & $1.483,49$ & $1.499,55$ & $1.469,98$ \\
\hline Real Estate & 261,44 & 285,16 & 290,44 \\
\hline
\end{tabular}

Citation: Apip Supriadi (2022). Leading Sector Using Overlay Analysis in Tasikmalaya City. Saudi J Bus Manag Stud, 7(1): 34-40. 
Apip Supriadi., Saudi J Bus Manag Stud, Jan, 2022; 7(1): 34-40

\begin{tabular}{|l|l|l|l|}
\hline Business Field & $\mathbf{2 0 1 8}$ & $\mathbf{2 0 1 9}$ & $\mathbf{2 0 2 0}$ \\
\hline Company Services & 165,08 & 182,17 & 156,63 \\
\hline Government Administration, Defense and Mandatory Social Security & 565,03 & 585,44 & 579,29 \\
\hline Education Services & 280,01 & 293,95 & 306,50 \\
\hline Health Services and Social Activities & 314,94 & 347,72 & 361,12 \\
\hline Other services & 405,80 & 428,76 & 424,39 \\
\hline Gross Regional Domestic Product & $14.859,11$ & $15.746,12$ & $15.430,02$ \\
\hline
\end{tabular}

Source: Central Bureau of Statistics, Tasikmalaya in Figures

For all economic sectors, the trend increases, especially in the manufacturing, construction, wholesale and retail trade sectors: car and motorbike repairs show the largest numbers. However, it is not known which sector is the leading sector of Tasikmalaya City economy from the economic sector. Therefore, researchers are interested in researching the Leading Sector by using overlay analysis in Tasikmalaya City.

\section{LITERATURE REVIEW}

The definition of the basic sector (leading sector) must be related to a form of comparison, whether it is a comparison on an international, regional or national scale. About the international scope, a sector is said to be superior if the sector can compete with the same sector as other countries. Meanwhile, with a national scope, a sector can be categorized as a leading sector if a certain area can compete with the same sector produced by other regions in the national or domestic market (Wijaya, 1996). If the sector becomes a base sector (leading) the sector must export its products to other regions, on the other hand if the sector becomes a non-base (not superior) sector, the sector must import the sector's products to other regions.

The theory of economic basis states that the main determinant of economic growth in a region is directly related to the demand for goods and services from outside the region (Arsyad, 2002). In the economic base theory (Economic base theory), the rate of economic growth of an area is determined by the size of the increase in exports in that region. Export activities are all activities, both product producers and service providers, that bring in money from outside the area, which are called basic activities to become the main driver of the economy in the region. Economic activities are grouped into basic activities and non-basic activities. Where only basic activities can encourage regional economic growth. Meanwhile, the non-basic economy makes goods needed within the scope of the surrounding community's economic area to meet their needs (Tarigan, 2014).

The basic economic theory essentially distinguishes basic sector activities and non-base sector activities. Base sector activity is the sector's growth that determines the area's overall development. In contrast, non-base sector activities are the secondary sector, which means that it depends on developments from the overall development (Arsyad, 1999).
According to Glasson (1990), the basic concept of the economic base divides the economy into two sectors, namely:

1. The basic sectors export goods and services to places outside the economic boundaries of the people concerned. So that the goods and services that are exported will generate regional income for the region itself.

2. Non-base sectors provide goods and services needed for the region itself that are within the economic limits of the local community. Regional income that can increase demand for the basic sector can also increase demand for the non-base sector because the non-base sector functions as a supporter of the basic sector.

The economic potential of an area is the economic capacity that exists in the area that is possible and feasible to be developed, so that it will continue to develop into a source of livelihood for the local people, and can even help the regional economy as a whole to develop by itself and sustainably (Soeparmoko, 2002). Potential/leading sectors must have advantages, namely comparatively superior and competitively superior. According to Arsyad (2010), several measures of economic growth can describe the relationship between the regional economy and the surrounding environment as a sector that supports economic growth in the area concerned, namely: 1) Location Quotient (LQ), 2) Growth Ratio Model (MRP), and 3) Overlay

Research related to leading sector analysis conducted in several regions in Indonesia, which has been carried out by Abdul Rajab, Rusli (2019)., Agus Tri Basuki and Utari Gayatri (2009), Alex Salenko Munthe, Zulgani; Hardiani (2019), Anna Yulianita (2009), Bramantyo Adi Nugroho (2017), Deris Desmawan, Rizal Syaifudin, Sugeng Setyadi, Randi Mamola (2021), Eucharist Jekna Mangilaleng, Debby Rotinsulu, and Wensy Rompas (2015), Fahrul Alam Masruri , Cahyono, Nugrahana Fitria Ruhyana (2021), Hajeri, Erlinda Yurisinthae (2015). Eva Dolorosa, Hamzah (2020), Herman Syahputra, Abubakar Hamzah, Mahmud Basuki, Febri Nugroho Mujiraharjo (2017), Ni Kadek Tasya Novita Devi, Ida Bagus Darsana(2019), Ni Made Winda Savitri Dewi, I Nyoman Mahaendra Yasa, Rahmah Farahdita Soeyatno (2018), Septi Rostika Anjani, Syarifah Ida Farida (2020), Yuni Purnama, Muhammad Nurjihadi, Fitriah Permata Cita (2017), Yusuf Hariyoko, Anggraeny Puspaningtyas (2020), stated that in general the leading sectors in each 
Apip Supriadi., Saudi J Bus Manag Stud, Jan, 2022; 7(1): 34-40

region are agriculture, construction and industrial sectors.

\section{RESEARCH METHODS}

This research uses descriptive and quantitative analysis. Descriptive analysis was compiled based on secondary data, journals, articles, and research results related to the topics raised. While quantitative analysis used Location Quotient Model (LQ), Growth Ratio Model (MRP), and Overlay Analysis to reflect the results and discussion expressed in numbers and to support the analysis, Microsoft Excel computer software was used to facilitate the calculation of the data needed in this study.

\section{Location Quotient Analysis}

Location Quotient analysis describes the relative comparison between the magnitude of the capacity of the investigated sector in an area with the same sector in a wider area (Tarigan, 2005). The formula for calculating LQ is as follows:

$\mathrm{LQ}=\frac{y i / y t}{Y i / Y t}$

Where

LQ = location quotient in Pangandaran Regency

$\mathrm{Yi}=$ GRDP sector $\mathrm{i}$ in Pangandaran Regency

$\mathrm{yt}=$ Total GRDP of Pangandaran Regency

$\mathrm{Yi}=$ GRDP sector $\mathrm{i}$ in West Java Province

$\mathrm{Yt}=$ Total GRDP of West Java province

Description

Based on the formulation shown above, three possible LQ values can be obtained, namely: First, the value of

LQ $=1$ this means that the level of specialization/sector i base in Pangandaran Regency is the same as the same sector in the economy of West Java Province.

LQ > 1 this means that the level of specialization/sector $i$ base in Pangandaran Regency is greater than the sector with the same sector in the economy of West Java Province

LQ $<1$ this means that the level of specialization/sector $\mathrm{i}$ base in Pangandaran Regency is smaller than the same sector in the economy of West Java Province

\section{Growth Ratio Model (MRP)}

Growth ratio model analysis is an analysis to compare the magnitude of the increase in income of an economic sector in a small area with a larger area. This analysis model has a range of values greater than, less than or equal to one. According to Suyana Utama (2010, 63-64), the model in this analysis is divided into two parts, namely:

\section{a. Study area growth ratio (RPs)}

comparison of income growth in the economic sector of the study area by reference.
$R P s=\underline{Y i j} / Y i j(t)$

Yin / Yin(t)

Yij = Change in GRDP sector $\mathrm{i}$ in the study area (Pangandaran Regency)

Yij (t) = GRDP of sector $\mathrm{i}$ in the study area at the beginning of the study (Pangandaran Regency)

Yin = Change in GRDP in the reference area (West Java Province)

Yin $(\mathrm{t})=$ GRDP of sector $\mathrm{i}$ in the reference area at the beginning of the study (West Java Province)

RPs = Comparison between the growth rate of sector $\mathrm{i}$ income in the study area and the growth rate of total GRDP in the reference area

b. Reference Area Growth Ratio (RPr) Comparison between the growth rate of economic sector income in the reference area and the total growth of the reference area.

$$
\text { RPs }=\frac{\text { Yin } / Y i n(t)}{Y n / Y n(t)}
$$

Description:

Yin $=$ change in GRDP sector $\mathrm{i}$ in the reference area (West Java Province)

Yin $(\mathrm{t})=$ GRDP of sector $\mathrm{i}$ in the reference area at the beginning of the study (West Java Province)

Yn $\quad=$ change in total GRDP in the reference area (West Java Province)

Yn $(\mathrm{t})=$ total GRDP in the reference area at the beginning of the study (West Java Province)

RPr = Comparison between the income growth rate of sector $\mathrm{i}$ in the reference area and the total growth rate (GRDP) of activity $i$ in the reference area

\section{Overlay Analysis}

Overlay analysis is carried out to see a description of potential economic activities developed in Central Java Province or find out potential sectors based on growth criteria and contribution criteria. In this case the Overlay technique is carried out to show the results of the combination of LQ and MRP. analysis

Overlay analysis describes potential economic activities, using growth criteria and comparative advantage criteria (Suyana Utama, 2010: 67). There are various categories of economic sectors that have different values, including:

1. Classification 1 is with a value of $(+++)$ which means that the sector's activities have high sectoral growth at the level of West Java and the level of Pangandaran Regency. Then the sectoral contribution of Pangandaran Regency is higher than West Java. This means that the sector has a 
Apip Supriadi., Saudi J Bus Manag Stud, Jan, 2022; 7(1): 34-40

high potential for competitiveness because it excels both at the district level and at the provincial level and it can be said that the sector has a competitive advantage.

2. Classification 2 has a value of (-++), where the RPr is negative, which means that the sector's activities have low sectoral growth at the level of West Java Province. And a positive value for RPs and LQ means that sectoral activities have high sectoral growth at the Pangandaran Regency level and the sectoral contribution of Pangandaran Regency is higher than West Java. In other words, the sector is a specialization of economic activity in Pangandaran Regency.

3. Classification 3 is with a value of (---), all of which are negative, which means that the sector has low sectoral growth at the level of West Java and
Pangandaran Regency and sectoral contribution in Pangandaran Regency is lower than West Java. This indicates that the economic sector has low competitiveness because it is not superior either at the district or provincial levels. And it can be said that the sector does not have a competitive advantage and is not a specialization of economic activity in Pangandaran Regency.

\section{RESULTS OF ANALYSIS AND DISCUSSION What economic sectors are included in the basic sector in Tasikmalaya City}

To find out the relative comparison between the magnitude of the capacity of the sector being investigated in an area with the same sector in a wider area, it can be seen in Table 2, as follows:

Table 2: Location Quotient (LQ) Calculation Results

\begin{tabular}{|l|l|}
\hline Category & Average LQ \\
\hline Agriculture, Forestry and Fisheries & 0,6 \\
\hline Mining and excavation & 0 \\
\hline Processing industry & 0,32 \\
\hline Electricity and Gas Supply & 0,03 \\
\hline Water Supply, Waste Management, Waste and Recycling & 4,4 \\
\hline Construction & 1,84 \\
\hline Wholesale and Retail Trade; Car and Motorcycle Repair & 1,57 \\
\hline Transportation and Warehousing & 2,03 \\
\hline Provision of Accommodation and Drinks & 1,82 \\
\hline Information and Communication & 0,98 \\
\hline Financial Services and Insurance & 3,92 \\
\hline Real Estate & 1,4 \\
\hline Company Services & 2,53 \\
\hline Government Administration, Defense and Mandatory Social Security & 2,01 \\
\hline Education Services & 0,66 \\
\hline Health Services and Social Activities & 2,69 \\
\hline Other services & 1,25 \\
\hline
\end{tabular}

Source: Central Bureau of Statistics, Tasikmalaya in Figures

Based on the Location Quotient calculation data in the table above, it can be seen that of the seventeen existing sectors, eleven sectors fall into the basic sector classification, namely sectors that have an average LQ>1, among others.

1. Water Supply, Waste Management, Waste and Recycling Sector

2. Construction Sector,

3. Wholesale and Retail Trade, Car and Motorcycle Repair,

4. Transportation and Warehousing Sector

5. Accommodation and Food and Drink Provision Sector

6. Financial Services and Insurance Sector

7. Real Estate Sector

8. Enterprise Service Sector

9. Government Administration Sector, Defense and Mandatory Social Security

10. Health Services and Social Activities Sector

11. Other Service Sector
It can be interpreted that the eleven sectors can meet the needs in Tasikmalaya City and can help meet the needs in other areas so that this sector is classified as a basic sector.

Based on the data from the Location Quotient calculation in the table above, it can be seen that eight sectors are included in the non-base sector classification, namely sectors that have an average LQ < 1, including:

1. Agriculture, Forestry and Fisheries Sector,

2. Mining and Quarrying Sector,

3. Manufacturing Industry Sector,

4. Electricity and Gas Procurement Sector,

5. Information and Communication Sector

6. Education Services Sector 
Apip Supriadi., Saudi J Bus Manag Stud, Jan, 2022; 7(1): 34-40

It can be interpreted that the six sectors cannot meet the needs in Tasikmalaya City so that these sectors are classified as non-basic sectors.
What economic sectors should be developed in Tasikmalaya City

To find out the comparison of the magnitude of the increase in income of an economic sector in the scope of a small area with a larger area, it can be seen in Table 3.

Table 3: Calculation Results of Growth Ratio Model (MRP) Analysis

\begin{tabular}{|l|l|l|}
\hline \multirow{2}{*}{ Kategori } & \multicolumn{3}{l}{ MRP } \\
\cline { 2 - 3 } & RPs & RPr \\
\hline Agriculture, Forestry and Fisheries & 0,30 & 0,64 \\
\hline Mining and excavation & $-0,19$ & $-0,88$ \\
\hline Processing industry & 1,50 & 0,84 \\
\hline Electricity and Gas Supply & $-0,78$ & $-1,36$ \\
\hline Water Supply, Waste Management, Waste and Recycling & 0,98 & 2,01 \\
\hline Construction & 1,21 & 1,07 \\
\hline Wholesale and Retail Trade; Car and Motorcycle Repair & 1,42 & 0,55 \\
\hline Transportation and Warehousing & 1,13 & 0,79 \\
\hline Provision of Accommodation and Drinks & 1,22 & 1,33 \\
\hline Information and Communication & 0,94 & 5,66 \\
\hline Financial Services and Insurance & 0,65 & 0,84 \\
\hline Real Estate & 1,02 & 2,40 \\
\hline Company Services & 2,67 & 0,35 \\
\hline Government Administration, Defense and Mandatory Social Security & 1,05 & 0,27 \\
\hline Education Services & 0,97 & 2,05 \\
\hline Health Services and Social Activities & 1,69 & 1,50 \\
\hline Other services & 1,05 & 1,58 \\
\hline
\end{tabular}

Source: Central Bureau of Statistics, Tasikmalaya in Figures

Based on the results of data analysis using the MRP method in the 2015 to 2019 period, it shows that there are 5 sectors included in the first classification with RPs and RPr values more than one which means that economic sector activities at the City and provincial levels are equally prominent. The sector is the construction sector; the sector of providing accommodation and food and drink; health services sector and social activities; health services sector and social activities; and other services.

For sectors belonging to the second classification with an RPs value of more than one and an RPr of less than one, which means that the sector has prominent economic activities at the City level. These sectors are the manufacturing industry sector; wholesale and retail trade sector; repair of cars and motorcycles; transportation and warehousing sector; corporate service sector; and the government administration, defense and mandatory social security sectors.

For the third classification, when the RPs value is less than one and the RPr exceeds one, the economic sector activities in the provincial area have a prominent development compared to the economic sector at the City level. Sectors classified as the third classification are the water supply, waste management, waste and recycling sectors; information and communication sector; and the education services.

The fourth classification with RPs and RPr values of less than one means that economic activities for certain sectors, both in the study area, namely the City and the reference area level, namely the province, are both not experiencing development in their growth or in this case the economy is not prominent in the sector. Sectors included in this classification are the agriculture, forestry and fishery sector, the mining and quarrying sector, and the electricity and gas procurement sector, and the financial and insurance services sector.

What economic sectors have the potential to be prioritized for development in Tasikmalaya City

For more details regarding the results of the overlay analysis, it can be seen in table 4, as follows: 
Apip Supriadi., Saudi J Bus Manag Stud, Jan, 2022; 7(1): 34-40

Table 4: Overlay Analysis Results

\begin{tabular}{|c|c|c|c|}
\hline \multirow[t]{2}{*}{ Kategori } & \multirow[t]{2}{*}{ LQ } & \multicolumn{2}{|c|}{ MRP } \\
\hline & & RPs & RPr \\
\hline Agriculture, Forestry and Fisheries & - & - & - \\
\hline Mining and excavation & - & - & - \\
\hline Processing industry & - & + & - \\
\hline Electricity and Gas Supply & - & - & - \\
\hline Water Supply, Waste Management, Waste and Recycling & + & - & + \\
\hline Construction & + & + & + \\
\hline Wholesale and Retail Trade; Car and Motorcycle Repair & + & + & - \\
\hline Transportation and Warehousing & + & + & - \\
\hline Provision of Accommodation and Drinks & + & + & + \\
\hline Information and Communication & - & - & + \\
\hline Financial Services and Insurance & + & - & - \\
\hline Real Estate & + & + & + \\
\hline Company Services & + & + & - \\
\hline Government Administration, Defense and Mandatory Social Security & + & + & - \\
\hline Education Services & - & - & + \\
\hline Health Services and Social Activities & + & + & + \\
\hline Other services & + & + & + \\
\hline
\end{tabular}

The results of the analysis of the economic sector overlay in Tasikmalaya City in 2015-2019 can be seen in the table above. It can be seen that the sectors that fall into the first classification are the construction sector, the accommodation and food and beverage supply sector, the real estate sector, the health services sector and social activities, and other service sectors with a positive overall value meaning that the five sectors have high sectoral growth and greater contribution in Tasikmalaya City compared to the Province of West Java. This shows that the sector has competitiveness because it has advantages at the City and provincial levels and must be developed.

The economic sector included in the second classification is where the sector has a negative symbol on the RPr side and positive on the LQ and RPs side, the sector is the wholesale and retail trade sector; repair of cars and motorcycles; the transportation and warehousing sector, the corporate service sector, and the government administration sector, defense and compulsory social security. This sector can be interpreted as a sector with low sectoral growth in West Java Province but has high sectoral growth and contribution in Tasikmalaya City. It can be said that the sector is a specialization of economic activity in Tasikmalaya City. This sector has a low growth compared to the total GRDP growth of West Java Province.

3 economic sectors are included in the third classification: agricultural, forestry, and fishery sectors; mining and quarrying, and electricity and gas procurement. The three sectors can have low sectoral growth both in Tasikmalaya City and West Java's Province. These sectors have a lower contribution in Tasikmalaya City than in West Java. It can be concluded that the two industries do have low competitiveness because they do not have advantages both in Tasikmalaya City and in the Province of West Java, so that the sector is included in the sector that does not have a competitive advantage.

\section{CONCLUSION}

Based on the results of the overlay analysis carried out by making 3 classifications of economic sectors based on existing provisions, the first and second classifications are sectors that must be development priorities by the local government of Tasikmalaya City which are expected to increase the rate of regional economic growth in Tasikmalaya City.

\section{REFERENCE}

- Arsyad, L. (2005). Pengantar Perencanaan dan Pembangunan Ekonomi Daerah, Edisi Kedua. Yogyakarta: BPFE.

- Abdul, R. R. (2019). Penentuan Sektor-Sektor Unggulan Yang Ada Pada Kabupaten Takalar Melalui Analisis Tipologi Klassen, Growth Jurnal Ilmiah Ekonomi Pembangunan, 1(1), 16-38.

- Agus Tri Basuki and Utari Gayatri, Penentu Sektor Unggulan Dalam Pembangunan Daerah: Studi Kasus di Kabupaten Ogan Komering Ilir, Jurnal Ekonomi dan Studi Pembangunan, 10(1), 34-50.

- Alex Salenko Munthe; Zulgani; Hardiani. (2019). Analisis pergeseran sektor unggulan Kabupaten Tanjung Jabung Barat, e-Jurnal Perspektif Ekonomi dan Pembangunan Daerah, 8(2).

- Anna, Y. (2009). Analisis Sektor Unggulan Dan Pengeluaran Pemerintah Di Kabupaten Ogan Komering Ilir, Jurnal Ekonomi Pembangunan Journal of Economic \& Development, 7.

- Arsyad, L. (1999). Pengantar Perencana dan pembangunan Ekonomi Daerah. Yogyakarta: BPFE. 
Apip Supriadi., Saudi J Bus Manag Stud, Jan, 2022; 7(1): 34-40

- Arsyad, L. (2002). Pengantar Perencanaan Ekonomi Daerah, edisi kedua. Yogyakarta: BPFE.

- Bramantyo Adi Nugroho, (2017). Analisis Sektor Unggulan Kabupaten Kutai Kartanegara Tahun 2010-2014, Jurnal “Gerbang Etam" Balitbangda Kab. Kukar 11(1).

- Deris Desmawan, Rizal Syaifudin, Sugeng Setyadi, Randi Mamola, (2021). Pertumbuhan Ekonomi Daerah: Sektor Ekonomi Unggul Kabupaten Pandeglang, 16(2).

- Ekaristi Jekna Mangilaleng, Debby Rotinsulu, dan Wensy Rompas (2015). Analisis Sektor Unggulan Kabupaten Minahasa Selatan, Jurnal Berkala Ilmiah Efisiensi 15(4).

- Fahrul Alam Masruri, Cahyono, Nugrahana Fitria Ruhyana. (2021). Analisis Penentuan Sektor Unggulan di Kabupaten Sumedang Provinsi Jawa Barat, Coopetition, Jurnal Ilmiah Manajemen, 12(1).

- Glasson, J. (1990). Pengantar Perencanaan Regional. Terjemahan oleh Paul Sitohang. LPFEUI, Jakarta

- Hajeri, Erlinda Yurisinthae, Eva Dolorosa. (2015). Analisis Penentuan Sektor Unggulan Perekonomian di Kabupaten Kubu Raya, Jurnal Ekonomi Bisnis dan Kewirausahaan 492), 253-269

- Hamzah. (2020). Analisis sub sektor industri pengolahan unggulan di Provinsi Kepulauan Bangka Belitung, SOROT: Jurnal Ilmu-ilmu Sosial 15(2), 75-85

- Herman Syahputra, Abubakar Hamzah, Sofyan Syahnur, (2015). Analisis Sektor Unggulan Dan Perubahan Struktur Perekonomian Kabupaten Aceh Barat, Jurnal Ilmu Ekonomi Pascasarjana Universitas Syiah Kuala, 3(3)

- Indrayansyah Nur, (2019). Analisis Pdrb Sektor Ekonomi Unggulan Provinsi Dki Jakarta, Indonesian Treasury Review Jurnal Perbendaharaan, Keuangan Negara Dan Kebijakan Publik, 4(4),351-370

- Kalzum R. J. (2018). Analisis Location Quotient dalam Penentuan Sektor Basis dan Non Basis di Kabupaten Gorontalo, Gorontalo Development Review, 1(1).
- Mahmud Basuki, Febri Nugroho Mujiraharjo. (2017). Analisis Sektor Unggulan Kabupaten Sleman dengan Metode Shift Share dan Location Quotient, Jurnal Sains, Teknologi dan Industri, 15(1), 52-60

- Ni Kadek Tasya Novita Devi, Ida Bagus Darsana. (2019). Analisis Sektor Unggulan Sebagai Basis Perencanaan Pembangunan Daerah Di Kabupaten Bangli, E-Jurnal EP Unud, 8910), 2405-2438

- Ni Made Winda Savitri Dewi, I Nyoman Mahaendra Yasa, Analisis Sektor Potensial Dalam Menetapkan Perencanaan Pembangunan Di Kabupaten Karangasem, E-Jurnal EP Unud, 7(1), 152-183.

- Rahmah, F. S. (2018). Analisis Penentuan Sektor Unggulan Terhadap Perekonomian Wilayah Kota Bogor Provinsi Jawa Barat Tahun 2012-2016 Jurnal Semarak, 1(3), 1-19.

- Septi Rostika Anjani, Syarifah Ida Farida. (2020). Analisis Sektor Unggulan Dan Perubahan Struktur Ekonomi Di Kabupaten/Kota Provinsi Banten, Research Journal of Accounting and Business Management (RJABM), 4(2)

- Suparmoko. (2002). Ekonomi publik untuk keuangan dan pembangunan daerah. Andi. Yogyakarta.

- Suyana Utama, I Made. (2010). Buku Ajar Ekonomi Regional. Denpasar: Fakultas Ekonomi Universitas Udayana

- Tarigan, R. (2014). Ekonomi Regional Teori dan Aplikasi. Jakarta: Bumi Aksara.

- Wijaya, A. (1996). Jurnal Ekonomi Pembangunan Pilihan Pembangunan Industri : Kasus DKI Jakarta. No IV (2), Jakarta.

- Yuni Purnama, Muhammad Nurjihadi, Fitriah Permata Cita. (2017). Sektor Unggulan Dan Pergeseran Struktur Dalam Meningkatkan Pertumbuhan Ekonomi NTB 2000-2015, Jurnal Ekonomi dan Bisnis, 2(2).

- Yusuf Hariyoko, Anggraeny Puspaningtyas. (2020). Analisis Pengembangan Sektor Unggulan Kota Surabaya 2013-2018, Jurnal Ilmu Administrasi Publik, 5(2), 110-116. 